\title{
Nonsense Mutations Affect C1 Inhibitor Messenger RNA Levels in Patients with Type I Hereditary Angioneurotic Edema
}

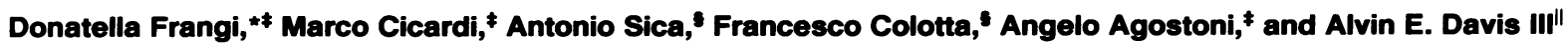 \\ *Division of Immunology, Children's Hospital, and Department of Pediatrics, Harvard Medical School, Boston, Massachusetts 02115; \\ ${ }^{\ddagger}$ Clinica Medica V, Universita di Milano, Ospedale S. Paolo, Milano, Italy; IInstituto di Recerche Farmacologiche "M. Negri," Milano, \\ Italy; and "Division of Nephrology, Children's Hospital Research Foundation, and Department of Pediatrics, \\ University of Cincinnati College of Medicine, Cincinnati, Ohio 45229
}

\begin{abstract}
Members of two unrelated families with type I hereditary angioneurotic edema (HANE) were found to have elevated levels of C1 inhibitor (C1INH) mRNA. DNA sequence analysis of PCR-amplified monocyte C1INH mRNA revealed normal and mutant transcripts, as expected in this disorder that occurs in heterozygous individuals. Single base mutations near the $3^{\prime}$ end of the coding sequence were identified in affected members of each family. One mutation consisted of insertion of an adenosine at position 1304 which created a premature termination codon (TAA), whereas the second consisted of deletion of the thymidine at position 1298 which created a premature termination codon (TGA) 23 nucleotides downstream. These mutations are $\sim 250$ nucleotides upstream of the natural termination codon. Nuclear run-off experiments in one kindred revealed no difference in transcription rates of the C1INH gene between the patients and normals. C1INH mRNA half-life experiments were not technically feasible because of the prolonged half-life of the normal transcript. Dideoxynucleotide primer extension experiments allowed the differentiation of the normal and mutant transcripts. These studies showed that the mutant transcript was not decreased relative to the normal, and this therefore was at least partially responsible for the C1INH mRNA elevation. This elevation may be due to the decreased catabolism of the mutant transcript. (J. Clin. Invest. 1991. 88:755759.) Key words: serpins $\bullet$ complement $\bullet$ premature termination codon $\bullet$ polymerase chain reaction $\bullet$ mRNA stability
\end{abstract}

\section{Introduction}

C1INH inhibitor $(\mathrm{C} 1 \mathrm{INH})^{1}$ is a serine proteinase inhibitor that plays a central role in the regulation of both the classical complement pathway and the contact activation pathway of the intrinsic coagulation and kinin-forming systems (1). The C1INH gene has been localized to chromosome 11 ; it is $\sim 17$

Address reprint requests to Alvin E. Davis III, Division of Nephrology, Children's Hospital Research Foundation, Elland and Bethesda Avenues, Cincinnati, OH 45229.

Received for publication 26 February 1991 and in revised form 7 May 1991.

1. Abbreviations used in this paper: $\mathrm{ClINH}, \mathrm{Cl}$ inhibitor; HANE, hereditary angioneurotic edema; PCR, polymerase chain reaction; RFLP, restriction fragment length polymorphism.

J. Clin. Invest.

(C) The American Society for Clinical Investigation, Inc.

0021-9738/91/09/0755/05 \$2.00

Volume 88, September 1991, 755-759 $\mathrm{kb}$ long with a coding region of $\sim 1,800 \mathrm{bp}(2-4)$. It consists of eight exons interrupted by introns that contain a high density of repetitive DNA sequences (Alu repeats), thus making the C1INH gene susceptible to rearrangements (4). Inherited deficiency of C1INH is known as hereditary angioneurotic edema (HANE). The disease is transmitted as an autosomal dominant trait (5). Individuals with HANE, at the molecular level, are heterozygous for defects within the CIINH gene. The main clinical feature of the disease is localized, recurrent, acute attacks of edema of the skin and mucosa (6). Acute attacks, especially of life-threatening laryngeal edema, can be prevented with androgen therapy or reversed with $\mathrm{C} 1 \mathrm{INH}$ concentrate $(7$, 8). There are two phenotypic variants of the disease. Type 1 HANE is characterized by low antigenic and functional plasma levels ( 5-30\% of the normals) of a normal C1INH protein. These patients represent the majority of HANE patients $(\sim 85 \%)$. Type 2 HANE is characterized by the presence of normal or elevated antigenic levels of a dysfunctional mutant protein together with reduced levels of the functional protein $(9,10)$. The available data suggest that a variety of mutations are responsible for $\mathrm{C} 1 \mathrm{INH}$ deficiency. Restriction fragment length polymorphism (RFLP) of the CIINH gene has been demonstrated in a minority of patients of both types (10-15\% of kindred) $(11,12)$. All RFLPs described in type I HANE have resulted from partial deletions or insertions within the CIINH gene and these all have involved Alu repetitive DNA $(13,14)$. Other mutations that may result in type I HANE have not been defined at the molecular level. Single base substitutions at the reactive center coding region have been shown to be the most common abnormality in type 2 HANE $(15,16$, Aulak, K. S., personal communication), although at least two other mutations, one a single base change and the other a codon deletion, have been observed $(17,18)$.

Studies at the mRNA level have demonstrated that levels of CIINH mRNA are $\sim 50 \%$ of normal in the majority of type I HANE patients, as might be expected with transcription of only one allele $(19,20)$. Some patients with deletions transcribe a small mRNA, which is present together with the normal transcript $(14,19,21)$. We also have identified two kindred with elevated quantities of a normal size C1INH message, despite the low antigenic and functional plasma levels of C1INH (22). In this study, we investigated the molecular genetic defects responsible for this abnormality in these two type 1 HANE families. Sequence analysis in each revealed single base mutations leading to the introduction of premature termination codons located near the $3^{\prime}$ end of the gene. The abnormal transcript was increased in concentration in one family and was present in quantities similar to the normal transcript in the other. The fact that the transcription rate does not show any variation compared with the normal suggests that the abnormal message 
is relatively stable despite the presence of a premature stop codon.

\section{Methods}

Patients. We have investigated two affected members from each of two different type 1 HANE families. All affected members of each kindred had clinical histories of recurrent episodes of angioedema. Multiple measurements of $\mathrm{C} 1 \mathrm{INH}$ levels in all affected individuals were always decreased, both by functional and immunochemical measurement. No RFLPs were demonstrated in these subjects (11). At the time of the analyses the patients had received no androgen or other therapy for at least one year.

RNA isolation. Total cellular RNA was isolated from adherent monocyte monolayers (23) by lysis with guanidinium isothiocyanate and centrifugation through cesium chloride density gradients (24). RNA was quantitated by absorbance at $260 \mathrm{~nm}$.

Northern blot analysis. Total cellular RNA $(10 \mu \mathrm{g})$ was denatured with formaldehyde and formamide and separated by electrophoresis in formaldehyde-containing agarose gels. Samples were transferred to nitrocellulose filters and hybridized with a CIINH cDNA probe ${ }^{32} \mathrm{P}-\mathrm{la}$ beled by nick translation (24), or with the oligolabeling method (25) (Oligolabelling Kit; Pharmacia Fine Chemicals, Piscataway, NJ).

Sequence amplification with the polymerase chain reaction (PCR). cDNA was synthesized from $1 \mu \mathrm{g}$ of patients' total RNA using AMV reverse transcriptase (Boehringer Mannheim, Inc., Indianapolis, IN). The cDNA was amplified using the automated PCR technique for 30 cycles with Taq I DNA polymerase (26) (Perkin-Elmer Corp., Norwalk, CT). Three sets of sense/antisense 30-bp-long oligonucleotides were synthesized with a DNA synthesizer (model 380B; Applied Biosystems, Foster City, CA). The primer sequences were designed to cover the entire CIINH cDNA coding sequence (3). Amplified cDNA was purified by electroelution (International Biotechnologies, Inc., New Haven, CT).

DNA sequencing. Amplified DNA was subcloned into pUC19 or pUC18 (Boehringer Mannheim, Inc.) and double-stranded DNA sequencing was performed by the dideoxynucleotide chain termination method (Sequenase Kit; United State Biochemical Corp., Cleveland, $\mathrm{OH})(27)$.

Dideoxynucleotide primer extension of $R N A$. After the identification of the mutations, dideoxy primer extension was carried out essentially according to Daar and Maquat (28). With this method, primer extension is done in the presence of three deoxynucleotides and the fourth is replaced with the appropriate dideoxynucleotide. Thus, the first position at which this base is incorporated will result in termination of extension. In the experiments here, a primer complementary to nucleotides 1305-1337 was used. The experiment was carried out using $20 \mu \mathrm{g}$ of total RNA from each patient and from a PLC/PRF/ 5 cell line (ATCC CRL 8024) as a control. One unit of Perfect Match Polymerase Enhancer (Stratagene, Inc., La Jolla, CA) was added to the annealing buffer before incubation. The primer was extended with ddCTP, dATP, dGTP, and dTTP (Pharmacia Fine Chemicals) by using AMV reverse transcriptase (Boehringer Mannheim, Inc.). The first cytosine incorporated by extension of this primer is at position 1293 producing a 12-nucleotide extension product. A single nucleotide deletion would be expected to result in an extension product one nucleotide shorter than the normal, whereas a single base insertion would be expected to result in an extension product one nucleotide longer. The lengths of extension products were determined by comparison with the migration of synthetic oligonucleotides run in parallel lanes.

CIINH mRNA half-life. To determine the half-life of C1INH mRNA in monocytes, gene transcription was blocked with actinomycin $\mathrm{D}(1 \mu \mathrm{g} / \mathrm{ml})$ and C1INH transcripts were detected at various intervals. The cellular mortality after $16 \mathrm{~h}$ of treatment with actinomycin D was $\sim \mathbf{3 0}-\mathbf{4 0 \%}$ as assessed by trypan blue dye exclusion. Total RNA was extracted and analyzed by Northern blot (24).
Nuclear run-off. Nuclear run-off experiments were performed essentially as described (29) with some modifications. To isolate nuclei, $5.0 \times 10^{7}$ monocytes were washed twice with ice cold HBSS with $\mathrm{Ca}^{++}$ and $\mathrm{Mg}^{++}$and then resuspended in $0.5 \mathrm{ml}$ lysis buffer (10 mM Tris$\mathrm{HCl}, \mathrm{pH} 7.4,3 \mathrm{mM} \mathrm{MgCl}, 10 \mathrm{mM} \mathrm{NaCl}, 0.5 \% \mathrm{NP}-40$ ). After $5 \mathrm{~min}$ incubation on ice, cells were centrifuged at $400 \mathrm{~g}$ at $4^{\circ} \mathrm{C}$ and resuspended in $250 \mu \mathrm{l}$ ice-cold freezing buffer (Tris- $\mathrm{HCl}, \mathrm{pH} \mathrm{8.3,40 \%} \mathrm{glyc-}$ erol, $5 \mathrm{mM} \mathrm{MgCl}, 0.1 \mathrm{mM}$ EDTA, pH 8$) .60 \mu 15 \times$ run-off buffer $(25$ $\mathrm{mM}$ Tris- $\mathrm{HCl}, \mathrm{pH} 8,12.5 \mathrm{mM} \mathrm{MgCl}, 750 \mathrm{mM} \mathrm{KCl}$, and $1.25 \mathrm{mM}$ each of dGTP, dCTP, and dATP), and $100 \mu \mathrm{Ci}{ }^{32} \mathrm{P}-\mathrm{UTP}(6,000 \mathrm{Ci} /$ mmol; Amersham Corp., Arlington Heights, IL) were added to $230 \mu \mathrm{l}$ of nuclei suspension and incubated at $30^{\circ} \mathrm{C}$ for $30 \mathrm{~min}$. Transcripts then were isolated using the guanidine/cesium chloride method with $50 \mu \mathrm{g}$ yeast mRNA added as carrier. The RNA pellet was resuspended in $180 \mu$ lice-cold TNE $(0.5 \mathrm{M}$ Tris- $\mathrm{HCl}, \mathrm{pH} 8,1.5 \mathrm{M} \mathrm{NaCl})$ and denatured with $20 \mu 12 \mathrm{~N} \mathrm{NaOH}$ on ice for $10 \mathrm{~min}$. The solution was neutralized by the addition of Hepes pH 7.2 (final concentration, $0.48 \mathrm{M}$ ). RNA was ethanol precipitated and dissolved in $100 \mu$ l hybridization solution (10 mM TES, $0.2 \%$ SDS, $10 \mathrm{mM}$ EDTA, $3 \mathrm{M} \mathrm{NaCl}$ ). The RNA solution was hybridized at $65^{\circ} \mathrm{C}$ for $48 \mathrm{~h}$ with DNA immobilized on nitrocellulose filters. In each experiment, each filter was hybridized with the same amount of ${ }^{32} \mathrm{P}$. The filters then were washed with $0.2 \times$ SSC at $65^{\circ} \mathrm{C}$ for $30 \mathrm{~min}$ and incubated at $37^{\circ} \mathrm{C}$ in $0.2 \times \mathrm{SSC}$ with 10 $\mathrm{Mg} / \mathrm{ml} \mathrm{RNase} \mathrm{A}$ for $30 \mathrm{~min}$. Filters then were exposed for autoradiography. For immobilization of DNA to filters, $5 \mu \mathrm{g}$ of plasmid containing CIINH cDNA was denatured with $0.3 \mathrm{M} \mathrm{NaOH}$ at $60^{\circ} \mathrm{C}$ for $30 \mathrm{~min}$, neutralized with ammonium acetate and spotted onto nitrocellulose filters using a slot blot apparatus (Shleicher \& Schuell, Keene, NH). pBR 322 DNA was used as a negative hybridization control. The plasmids used contained a murine c-fos genomic clone (pc-fos-3) (30) and a c-jun cDNA (clone AH119) (31) and a full-length cDNA coding for C1INH subcloned in the Hind III and Sal I sites of the Genescribe-Z pTZ18R vector.

\section{Results}

Northern blot analysis. Northern blot analysis demonstrated the presence of elevated levels of normal sized specific C1INH mRNA in the patients from the two type 1 kindred analyzed (Fig. 1). To confirm these data the analysis was repeated on samples obtained at different times from the same subjects and no variation was found (data not shown).

Sequence analysis. Sequence analysis of PCR-amplified DNA revealed the presence of single base mutations in both

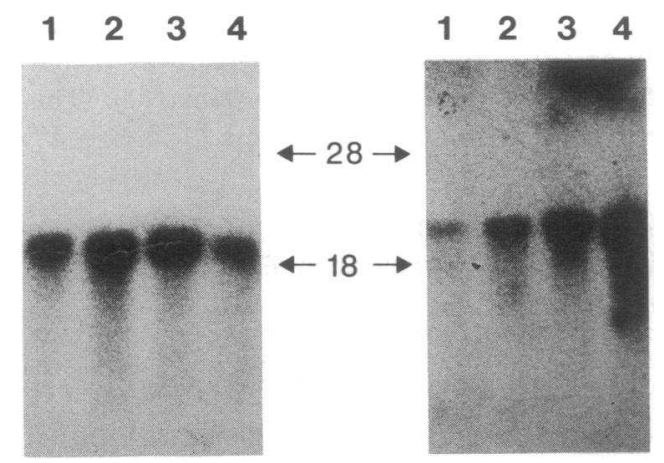

Figure 1. Northern blot analysis of actin mRNA (left) and C1INH mRNA (right) from monocyte monolayers from a normal individual (lane 2) and three different type I HANE patients (lanes 1, 3, and 4). The sample in lane 1 was from a family in which the CIINH mRNA is present at levels $\sim 50 \%$ of normal (19). The samples in lanes 3 and 4 are from family 2 and family 1 , respectively. 
families in addition to clones with sequences corresponding to the normal allele. In the first family (Fig. 2) the mutation consisted of the insertion of an adenosine at nucleotide 1304 leading to the creation of a premature termination codon (TAA) at a position corresponding to amino acid 401 of the normal C1INH protein. In the second family (Fig. 3) deletion of a thymidine was present at position 1298 creating a premature termination codon (TGA) 23 nucleotides downstream (not shown). Interestingly, the mutations are located very near one another within the coding region in exon 8 , the last exon of the C1INH gene. This region is located upstream from the C1INH reactive center (nucleotides 1331-1333), and $\sim 250$ nucleotides from the natural termination codon. There were no other alterations in the complete coding sequences of the mutant alleles from each of the families. In confirmation of the heterozygous nature of the defect, clones also were identified with completely normal sequences. The mutations were confirmed in both affected members of each family and on different preparations of PCR-amplified DNA.

Dideoxynucleotide primer extension. To differentiate between the transcripts from the normal and the mutated alleles and to confirm that both alleles are transcribed, we performed dideoxynucleotide primer extension (28). With this procedure, the two alleles can be distinguished on the basis of sequence heterogeneity. Using ddCTP as the terminating nucleotide the primer was extended 12 nucleotides (1304-1293) in the normal allele (Fig. 4, lane 3), 11 nucleotides in the allele with the deletion (Fig. 4, lane 2), and 13 nucleotides in the allele with an insertion (Fig. 4, lane 1). This experiment allowed the demonstration that the abnormal transcript is present in concentrations equal to (family 1, Fig. 4, lane 1 ) or greater than (family 2 , Fig. 4, lane 2) the concentration of the normal transcript.

Half-life and nuclear run-off. To analyze the mechanisms leading to the increased level of mRNA in these patients, we attempted to investigate both transcription rate and RNA stability. However, the RNA stability experiments were not reliable because of the long half-life (over $16 \mathrm{~h}$ ) of the normal CIINH mRNA. The data beyond $16 \mathrm{~h}$ were inaccurate because of spontaneous mortality of the cells treated with actinomycin D. Nuclear run-off assays revealed no difference in the transcription rate between two different normal individuals and a member of family 1 (Fig. 5), thus indicating that the increase of total C1INH mRNA in this family was not due to an increased transcription rate. No member of family 2 was available for this study.
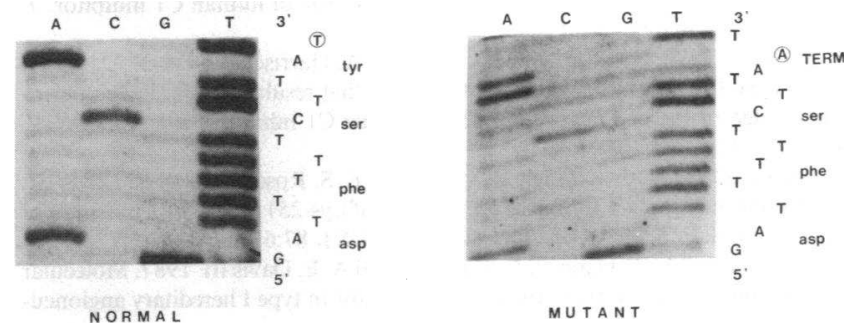

Figure 2. Sequence analysis of PCR-amplified DNA from the normal and mutant alleles of family 1 . The sequence shown in each case corresponds to the coding strand. In the mutant allele, an adenosine (circle) is inserted between the adenosine and thymidine (circle) encoding tyrosine- 401 of the normal allele.
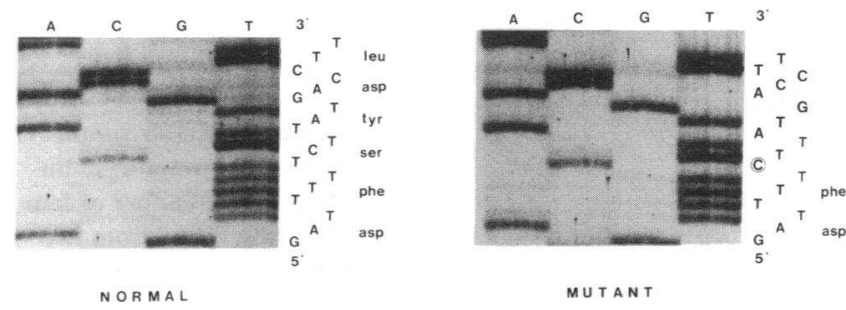

Figure 3. Sequence analysis of PCR-amplified DNA from the normal and mutant alleles of family 2 . The sequence shown in each case corresponds to the coding strand. A thymidine present in the codon for serine- 400 in the normal allele is deleted in the mutant allele.

\section{Discussion}

The mutations leading to C1INH deficiency in the two described families with type 1 HANE were single base substitutions that resulted in the introduction of premature termination codons in the last exon of the CIINH gene. Northern blot analysis showed elevated levels of C1INH-specific mRNA in these subjects despite the low antigenic and functional levels of C1INH protein in plasma (Fig. 1). These elevated C1INH mRNA levels were observed in multiple RNA samples from each family over a period of $3 \mathrm{yr}$ (data not shown). Earlier studies have shown that the majority of kindred with type I HANE reveal levels of C1INH mRNA that are, at most, $50 \%$ of normal levels $(19,20,32)$. Some patients with partial deletions reveal two transcripts: a normal mRNA present at concentrations $\sim 50 \%$ of normal; and a smaller transcript of the partially deleted allele which is at similar or lower concentrations. In the two families described here, the dideoxynucleotide primer extension studies prove that both alleles are, in fact, transcribed. In one family, the normal and abnormal transcripts appear to be similar in concentration (Fig. 4, lane 1), whereas in the

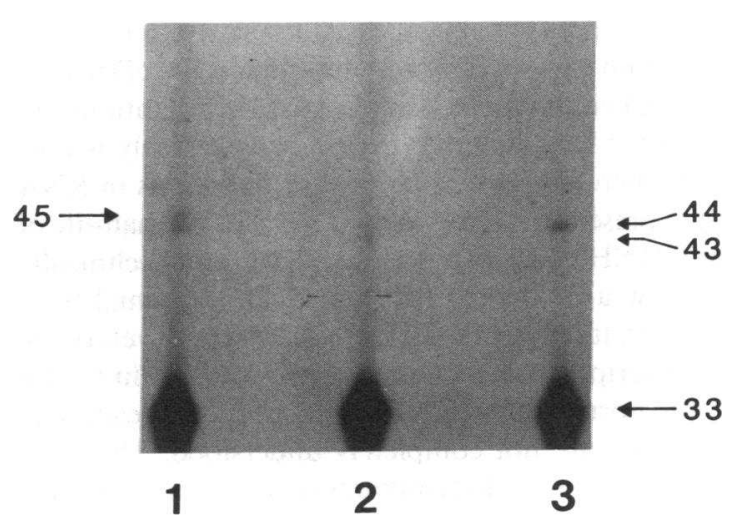

Figure 4. Dideoxy primer extension of monocyte mRNA from a normal individual (lane 3 ) and from members of family 1 (lane 1 ) and family 2 (lane 2 ). The normal mRNA extends 11 nucleotides to guanine-1293 to give a 44-nucleotide product (lane 3). The mRNA from family 1 , the family with insertion of an adenosine between nucleotides 1303 and 1304 extends to reveal two products of approximately equal intensity, at $\mathbf{4 4}$ and 45 nucleotides (lane 1 ). The mRNA from an affected member of family 2 reveals extension products of 44 and 43 nucleotides (lane 2). These products were difficult to photograph, but the smaller deletion product was of much greater intensity that the normal 44 nucleotide product. 


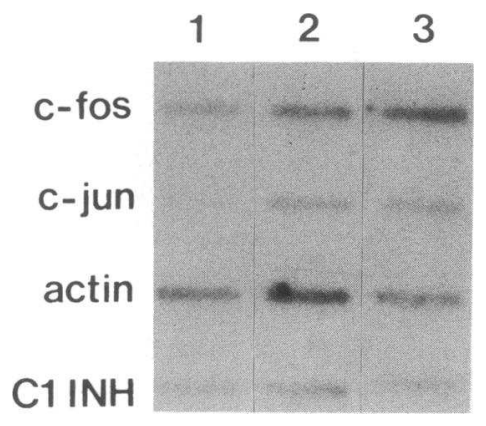

Figure 5. Nuclear runoff assays using monocyte nuclei from a member of fam. ily 1 (lane 1 ) and from two different normal individuals (lanes 2 and 3 ). The CIINH mRNA relative to control transcripts was not increased over the normals.

other, the mutant transcript is present in larger quantities (Fig. 4, lane 2). Thus, the elevated mRNA levels are, at least partially, a result of an increase in concentration of the abnormal transcript. It was not possible to detect any smaller C1INH protein in sera from these patients after immunoprecipitation with anti-C1INH antiserum (data not shown). Only C1INH of normal size was observed. Therefore, it is not known whether the abnormal mRNA is not translated or if it is translated into an unstable truncated C1INH protein.

There is growing evidence that nonsense mutations are not always associated with decreased levels of steady-state mRNA, as previously reported $(28,33-35)$. Normal levels of mRNA have been shown for the LDL receptor (36), for the beta-globin chain (37) and for apolipoprotein CII (38) in patients with nonsense mutations of these genes. Similar findings were reported for the dihydrofolate reductase gene in which nonsense mutations were artificially introduced at various points in the gene sequence (39). These data all indicate that the closer a mutation is to the $3^{\prime}$ end of a gene the higher the levels of abnormal mRNA. The mechanisms leading to alterations in mRNA levels with premature termination codons are not clearly understood. They may involve differences in transcription rate, in the efficiency of processing and transport to the cytoplasm or in the stability of intracellular mRNA. In these C1INH-deficient patients, no difference in transcription rate was found compared with normal, as shown by the nuclear run-off experiments. Because no abnormality was detected in the cDNA sequence at the splice junctions, and because the mutations are located within the last exon, RNA splicing very likely is normal. There is, therefore, no evidence that alterations in RNA processing are present in these patients. Because the half-life of the normal C1INH mRNA is so long, it was not technically possible to show a prolonged half-life of the abnormal transcripts. However, it remains possible that elevated levels of the abnormal transcripts may be due to enhanced stability compared with the normal transcript. The mechanisms leading to increased stability are not completely understood. There appear to be many different determinants involved in the regulation of mRNA stability, including structures located near the 3' end of the mRNA (such as the poly(A) tail), and modification of mRNA secondary structures (40-43). The length of the poly(A) sequence was the same in the abnormal message from the patients described here as in the normal (data not shown). Analysis of the mRNA sequences from these patients using PC/Gene (Intelligenetics, Inc., Mountain View, CA) revealed no apparent difference from the normal C1INH mRNA secondary structure. It also has been suggested that a block in protein elongation per se may be responsible for a longer halflife of some mRNA species (44). Further studies will be re- quired to determine whether in these patients there is a relationship between translation and mRNA levels.

\section{Acknowledgments}

This work was supported by United States Public Health Service Grant HD22082 and by the March of Dimes Birth Defect Foundation Grant $1-775$.

\section{References}

1. Davis, A. E., III. 1988. C1 inhibitor and hereditary angioneurotic edema. Annu. Rev. Immunol. 6:595-628.

2. Davis, A. E., III, A. S. Whitehead, R. A. Harrison, A. Dauphinais, G. A. P. Bruns, M. Cicardi, and F. S. Rosen. 1986. Human C1 inhibitor: characterization of cDNA clones and localization of the gene to chromosome 11. Proc. Natl. Acad. Sci. USA. 83:3161-3165.

3. Bock, S. C., K. Skriver, E. Nielsen, M. C. Thogersen, B. Wiman, V. H. Donaldson, R. L. Eddy, J. Marrinan, E. Radziejewska, R. Huber, T. Shows, and S. Magnusson. 1986. Human $\mathrm{Cl}$ inhibitor: primary structure, cDNA cloning and chromosomal localization. Biochemistry. 25:4292-4301.

4. Carter, P. E., B. Dunbar, and J. E. Fothergill. 1988. Genomic and cDNA cloning of the human $\mathrm{Cl}$ inhibitor: intron-exon junctions and comparison to other serpins. Eur. J. Biochem. 173:163-169.

5. Donaldson, V. H., and R. R. Evans. 1963. A biochemical abnormality in hereditary angioneurotic edema. Am. J. Med. Sci. 35:37-44.

6. Cicardi, M., L. Bergamaschini, B. Marasini, G. Boccassini, A. Tucci, and A. Agostoni. 1982. Hereditary angioedema: an appraisal of 104 cases. Am. J. Med. Sci. 284:2-9.

7. Gelfand, J. A., R. J. Sherins, D. W. Alling, and M. M. Frank. 1976. Treatment of hereditary angioedema with danazol. Reversal of clinical and biochemical abnormalities. $N$. Engl. J. Med. 295:1444-1448.

8. Bergamaschini, L., M. Cicardi, A. Tucci, M. Gardinali, D. Frangi, C. Valle and A. Agostoni. 1983. C1INH concentrate in the therapy of hereditary angioedema. Allergy. 38:81-84.

9. Rosen, F. S., C. A. Alper, J. Pensky, M. R. Klemperer, and V. H. Donaldson. 1971. Genetically determined heterogeneity of the $\mathrm{Cl}$ esterase inhibitor in patients with hereditary angioneurotic edema. J. Clin. Invest. 50:2143-2149.

10. Gadek, J. E., S. W. Hosea, J. A. Gelfand, and M. M. Frank. 1979. Response of variant hereditary angioedema phenotypes to danazol therapy. J. Clin. Invest. 64:280-286.

11. Cicardi, M., T. Igarashi, M. S. Kim, D. Frangi, A. Agostoni, and A. E. Davis III. 1987. Restriction fragment length polymorphism of the $\mathrm{Cl}$ inhibitor gene in hereditary angioneurotic edema. J. Clin. Invest. 80:1640-1643.

12. Stoppa-Lyonnet, D., M. Tosi, J. Laurent, A. Sobel, G. Lagrue, and T. Meo. 1987. Altered $\mathrm{Cl}$ inhibitor genes in type I hereditary angioedema. $N$. Engl. J. Med. 317:1-6.

13. Stoppa-Lyonnet, D., P. E. Carter, T. Meo, and M. Tosi. 1990. Clusters of intragenic Alu repeats predispose the human $\mathrm{Cl}$ inhibitor locus to deleterious rearrangements. Proc. Natl. Acad. Sci. USA. 87:1551-1555.

14. Ariga, T., P. E. Carter, and A. E. Davis III. 1990. Recombinations between Alu repeat sequences that result in partial deletions within the $\mathrm{C} 1$ inhibitor gene. Genomics. 8:607-613.

15. Aulak, K. S., P. A. Pemberton, F. S. Rosen, R. W. Carrell, P. J. Lachmann, and R. A. Harrison. 1988. Dysfunctional C1 inhibitor (At), isolated from a type II hereditary-angio-oedema plasma, contains a P1 'reactive centre' ( $\mathrm{Arg}^{444}$-His) mutation. Biochem. J. 253:615-618.

16. Skriver, K., E. Radziejewska, J. A. Silbermann, V. H. Donaldson, and S. C. Bock. 1989. CpG mutations in the reactive site of human $\mathrm{Cl}$ inhibitor. $J$. Biol. Chem. 264:3066-3071.

17. Levy, N. J., N. Ramesh, M. Cicardi, R. A. Harrison, and A. E. Davis III. 1990. Type II hereditary angioneurotic edema that results from a single nucleotide change in the codon for alanine-436 in the $\mathrm{Cl}$ inhibitor gene. Proc. Natl. Acad. Sci. USA. 87:265-268.

18. Parad, R. B., J. Kramer, R. C. Strunk, F. S. Rosen, and A. E. Davis III. 1990. Dysfunctional $C 1$ inhibitor Ta: deletion of Lys-251 results in acquisition of an $N$-glycosylation site. Proc. Natl. Acad. Sci. USA. 87:6786-6790.

19. Cicardi, M., T. Igarashi, F. S. Rosen, and A. E. Davis III. 1987. Molecular basis for the deficiency of complement 1 inhibitor in type I hereditary angioneurotic edema. J. Clin. Invest. 79:698-702.

20. Lappin, D. F., A. R. McPhaden, P. L. Yap, P. E. Carter, G. D. Birnie, J. E. Fothergill, and $\mathrm{K}$. Whaley. 1989. Monocyte $\mathrm{Cl}$ inhibitor synthesis in patients with $\mathrm{Cl}$ inhibitor deficiency. Eur. J. Clin. Invest. 19:45-52.

21. Tosi, M., P. Bourgarel, C. Brazzali, C. Duponchel, D. Stoppa-Lyonnet, M. Meo. 1990. Intracellular retention of $\mathrm{Cl}$ inhibitor in two hereditary angioedema patients. Comp. Inflam. 7:199. (Abstr.) 
22. Cicardi, M., T. Igarashi, M. S. Kim, D. Frangi, A. Agostoni, F. S. Rosen, and A. E. Davis III. 1987. Genetic heterogeneity of hereditary angioneurotic edema. Clin. Res. 35:606a. (Abstr.)

23. Einstein, L. P., E. E. Schneeberger, and H. R. Colten. 1976. Synthesis of the second component of complement by long-term primary culture of human monocytes. J. Exp. Med. 143:114-126.

24. Chirgwin, J. M., A. E. Pryzbla, R. J. MacDonald, and W. J. Rutter. 1979. Isolation of biologically active ribonucleic acid from sources enriched in ribonuclease. Biochemistry. 18:5294-5299.

25. Feinberg, A. P., and B. Vogelstein. 1983. A technique for radiolabelling DNA restriction endonuclease fragments to high specific activity. Anal. Biochem. 132:6-13.

26. Mullis, K. B., and F. Faloona. 1987. Specific synthesis of DNA in vitro via a polymerase catalyzed chain reaction. Methods Enzymol. 155:335-350.

27. Sanger, F., S. Nicklen, and R. A. Coulson. 1977. DNA sequencing with chain-terminating inhibitors. Proc. Natl. Acad. Sci. USA. 74:5463-5467.

28. Daar, I. O., and L. E. Maquat. 1988. Premature translation termination mediates triosephosphate isomerase mRNA degradation. Mol. Cell. Biol. 8:802813.

29. Greenberg, M. E., and E. B. Ziff. 1984. Stimulation of 3 T3 cells induces transcription of the c-fos proto-oncogene. Nature (Lond.) 311:433-438.

30. Miller, A. D., T. Curran, and I. M. Verma. 1984. c-fos protein can induce cellular transformation: a novel mechanism of activation of a cellular oncogene. Cell. 36:51-60.

31. Ryseck, R. P., S. I. Hiray, M. Yaniv, and R. Bravo. 1988. Transcriptional activation of c-jun during the GO/G1 transition in mouse fibroblasts. Nature (Lond.) 334:535-537.

32. Kramer, J., Y. Katz, F. S. Rosen, A. E. Davis III, and R. C. Strunk. 1991. Synthesis of $\mathrm{Cl}$ inhibitor in fibroblasts from patients with type I and type II hereditary angioneurotic edema. J. Clin. Invest. In press.

33. Baserga, S. J., and E. J. Benz, Jr. 1988. Nonsense mutations in the human $\beta$-globin gene affect mRNA metabolism. Proc. Natl. Acad. Sci. USA. 85:20562060.
34. Humphries, K. R., T. J. Ley, N. P. Anagnou, A. W. Baur, and A. W. Nienhuis. 1984. $\beta$-39 thalassemia gene. A premature codon causes $\beta$ mRNA deficiency mutant without affecting cytoplasmic $\beta$ mRNA stability. Blood. 64:23-32.

35. Atweh, G. F., H. E. Brickner, X. X. Zhu, H. M. Kararian, Jr., and B. G. Forget. 1988. New amber mutation in a $\beta$-thalassemic gene with nonmeasurable levels of mutant messenger RNA in vivo. J. Clin. Invest. 82:557-561.

36. Lehrmann, M. A., W. J. Schneider, M. S. Brown, C. G. Davis, A. Elhamer, D. W. Russel, and J. L. Goldstein. 1987. The lebanese allele at low density lipoprotein receptor locus: nonsense mutation produces truncated receptor that is retained in endoplasmic reticulum. J. Biol. Chem. 262:401-410.

37. Liehaber, S. A., M. B. Coleman, J. G. Adams III, F. E. Cash, and M. H. Steinberg. 1987. Molecular basis for nondeletion $\alpha$-thalassemia in American Blacks $2^{116 G A G \rightarrow U A G} J$. Clin. Invest. 80:154-159.

38. Fojo, S. S., P. Lohse, C. Parrot, G. Baggio, C. Gabelli, F. Thomas, J. Hoffman, and H. B. Brewer, Jr. 1989. A nonsense mutation in the apolipoprotein

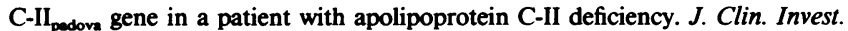
84:1215-1219.

39. Carothers, A. M., R. W. Steingenwalt, G. Urlaub, L. A. Chasin, and D. Grunberger. 1989. DNA base changes and RNA levels in $\mathrm{N}$-acetoxy-2-acetylaminofluorene-induced dihydrofolate reductase mutant of chinese hamster ovary cells. J. Mol. Biol. 208:417-428.

40. Brawerman, G. 1987. Determinants of messenger RNA stability. Cell. 48:5-6.

41. Nilsson, G., J. G. Belasco, S. N. Cohen, and A. von Gabain. 1984. Growth-rate dependent regulation of mRNA stability in Escherichia coli. Nature (Lond.) 312:75-77.

42. Jaeck, H. M., J. Berg and M. Wabl. 1989. Translation affects immunoglobin mRNA stability. Eur. J. Immunol. 19:843-847.

43. Peltz, S. W., and J. Ross. 1987. Autogenous relation of histone mRNA decay by histone proteins in a cell-free system. Mol. Cell. Biol. 7:4345-4356.

44. Gay, D. A., S. S. Sisodia, and D. W. Cleveland. 1989. Autoregulatory control of $\beta$-tubulin mRNA stability is linked to translation elongation. Proc Natl. Acad. Sci. USA. 89:5763-5767. 